\title{
A Novel Dry Treatment for Municipal Solid Waste Incineration Bottom Ash for the Reduction of Salts and Potential Toxic Elements
}

\author{
Marco Abis ${ }^{1, *(D)}$, Martina Bruno ${ }^{2} \mathbb{D}$, Franz-Georg Simon ${ }^{3} \mathbb{D}$, Raul Grönholm ${ }^{4}$, Michel Hoppe ${ }^{5}$, Kerstin Kuchta ${ }^{1}$ \\ and Silvia Fiore $2, *$ (D)
}

1 SRWM (Sustainable Resource and Waste Management), Hamburg University of Technology, 21079 Hamburg, Germany; kuchta@tuhh.de

2 DIATI (Department of Engineering for Environment, Land and Infrastructures), Politecnico di Torino, 10129 Torino, Italy; martina.bruno@polito.it

3 Bundesanstalt für Materialforschung und -Prüfung (BAM), 12200 Berlin, Germany; franz-georg.simon@bam.de

4 Sysav Utveckling AB, 20025 Malmö, Sweden; Raul.Gronholm@sysav.se

5 Heidemann Recycling GmbH, 28277 Bremen, Germany; m.hoppe@heidemann-recycling.de

* Correspondence: marco.abis@tuhh.de (M.A.); silvia.fiore@polito.it (S.F.)

Citation: Abis, M.; Bruno, M.; Simon, F.-G.; Grönholm, R.; Hoppe, M.;

Kuchta, K.; Fiore, S. A Novel Dry

Treatment for Municipal Solid Waste Incineration Bottom Ash for the

Reduction of Salts and Potential Toxic

Elements. Materials 2021, 14, 3133.

https://doi.org/10.3390/ma14113133

Academic Editor: Antonio Gil Bravo

Received: 14 April 2021

Accepted: 21 May 2021

Published: 7 June 2021

Publisher's Note: MDPI stays neutral with regard to jurisdictional claims in published maps and institutional affiliations.

\begin{abstract}
The main obstacle to bottom ash (BA) being used as a recycling aggregate is the content of salts and potential toxic elements (PTEs), concentrated in a layer that coats BA particles. This work presents a dry treatment for the removal of salts and PTEs from BA particles. Two pilotscale abrasion units (with/without the removal of the fine particles) were fed with different BA samples. The performance of the abrasion tests was assessed through the analyses of particle size and moisture, and that of the column leaching tests at solid-to-liquid ratios between 0.3 and 4 . The results were: the particle-size distribution of the treated materials was homogeneous ( $25 \mathrm{wt} \%$ had dimensions $<6.3 \mathrm{~mm}$ ) and their moisture halved, as well as the electrical conductivity of the leachates. A significant decrease was observed in the leachates of the treated BA for sulphates (44\%), chlorides (26\%), and PTEs (53\% Cr, 60\% Cu and 8\% Mo). The statistical analysis revealed good correlations between chloride and sulphate concentrations in the leachates with $\mathrm{Ba}, \mathrm{Cu}, \mathrm{Mo}$, and $\mathrm{Sr}$, illustrating the consistent behavior of the major and minor components of the layer surrounding BA particles. In conclusion, the tested process could be considered as promising for the improvement of BA valorization.
\end{abstract}

Keywords: bottom ash; dry treatment; incineration; municipal solid waste; potential toxic elements; salts

\section{Introduction}

The mining of mineral aggregates is the largest extractive sector in the EU, which, on its own, exceeds the amount of all the minerals produced [1]. Nevertheless, its End-of-Life (EoL) input rate was estimated to be only $8 \mathrm{wt} \%$. Typical EoL materials used as aggregates are construction and demolition waste (CDW) and bottom ash (BA) from municipal solid waste incineration (MSWI). However, the full recycling potential of these waste flows have not been tapped yet due to the existing gap between market prices and extraction, processing, and transportation costs [2].

BA is the main by-product of MSWI and counts approximately $25 \mathrm{wt} \%$ of MSW input for thermal valorization [3,4]; 71 Mt of MSW incinerated in Europe in 2018 produced about $18 \mathrm{Mt}$ of BA. Current full-scale material recovery technologies applied to BA mainly focus on the separation of metals, with the most valuable components being aluminum and copper [5,6]; this leaves the mineral fraction unexploited, and which is usually landfilled. The mineral fraction has been estimated at 85-90 wt \% of BA [4], resulting in 15-16 Mt/y 
of materials in Europe that could potentially be recycled as aggregates. Several studies have recently explored recycling alternatives for the BA mineral fraction to be used as construction material, e.g., as the sub-base layer for asphalt roads [7], as the source of construction sand [8] and as substitute material for concrete production $[9,10]$. The recycling of the BA mineral fraction as a secondary aggregate holds the potential of enhancing the profitability of BA management and is fully consistent with EU policy on Circular Economy. Material recovery from BA could entail a significant improvement in the circularity of the management of resources, not only limiting the request for primary aggregates but more particularly reducing the amount of waste sent to the landfill. Despite the low commercial value of secondary mineral aggregates, potential savings from landfill fees could entail significant economic benefits and ensure the profitability of BA mineralfraction management. The production of primary aggregates in Europe in 2018 was $2431 \mathrm{Mt}$, which was composed of sand, gravel, and crushed rocks [11]. Considering this mass, the mineral fraction of BA could potentially replace $0.7 \mathrm{wt} \%$ of primary aggregates produced in Europe. This value was consistent with a recent study [12], which estimated a $0.6 \%$ potential substitution rate. Nonetheless, since about $806 \mathrm{Mt}$ of non-hazardous waste generated in Europe are currently disposed in landfills, the recycling of the BA mineral fraction as a secondary aggregate might divert circa $2 \mathrm{wt} \%$ of the waste stream directed to landfills.

However, the potential reuse of the BA mineral fraction as a secondary aggregate is hindered by the presence of Potential Toxic Elements (PTEs) [13], which have negative environmental impacts [14,15]. Among the PTEs, cadmium, chromium, and molybdenum were the most found in MSWI BA [16,17]. Most European countries set threshold limits for recycled aggregates due to PTEs and chloride and sulphate leaching. A detailed analysis of the different leaching tests applied to BA and related limits in Europe were presented in a recent study [12]. In this framework, special attention should be devoted to studying BA composition, not only to detect the mineral phases for further geochemical dissolution modelling, but also to map their occurrence and locations in the solids. X-ray diffraction analyses (XRD), energy dispersive X-ray spectroscopy (EDX), and Scanning Electron Microscopy (SEM) were some analytical techniques adopted for such investigations. The key result of those characterization studies [18] was that the presence of chloride and sulphate salts is mostly limited to the surface layer coating the coarser BA particles. This observation justified the strong drops in chloride concentration observed by different authors $[5,14,19]$ while performing percolation leaching tests on BA after washout and dissolution treatments. Similarly, the presence of other sparingly soluble salts, such as calcium sulphate and their similar releasing mechanisms, also suggests their accumulation in a layer coating the coarser BA particles. Finally, the existence of several PTEs was linked with the presence of calcite $\left(\mathrm{CaCO}_{3}\right)$, melilite, and iron oxides [16], and weathering products such as gypsum, ettringite, and zeolite have been proven to contain high amounts of PTEs.

Several efforts have been devoted to reducing the amounts of salts $[20,21]$ and of the metals $\mathrm{Zn}, \mathrm{Cu}$, and $\mathrm{Ni}$ [22] from BA through the application of intensive washing processes, which were proven to be rather effective in the removal; however, run-off waters resulted as contaminated from the presence of heavy metals, chlorides, and sulphates [23]. Particularly, concern arose from the leaching of copper [24] and antimony [25], exceeding wastewater discharge limits. Therefore, wet processes aimed at reducing the leaching of salts and PTEs from the mineral fraction of BA, even if effective, still presented several critical downstream issues (e.g., wastewater treatment, sludge thickening, and disposal) in need of optimization. To our knowledge, no literature is available on dry treatment processes applied to the mineral fraction of $\mathrm{BA}$; a dry process, if effective in reducing the release of salts and PTEs, could avoid any wastewater in need of further treatment. In this study, a novel dry treatment process was explored, based on the findings that most of the salts and PTEs released from BA are located on a thin, superficial layer coating coarser BA particles, which can be selectively removed by controlling the mutual abrasion of the particles in a tumbling mill. More precisely, while processing aggregates in a tumbling mill, 
the grinding of the material occurs. Grinding is driven by three main mechanisms [26]: impact (compression), chipping (attrition), and abrasion [27] when applied with normal, oblique, and parallel forces, respectively (Figure 1). The main objective of this study was to avoid and minimize the compression and chipping forces, and to maintain BA coarseness, while promoting the abrasion on the particles' surfaces.

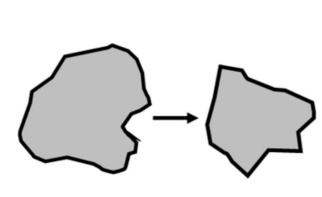

(a)

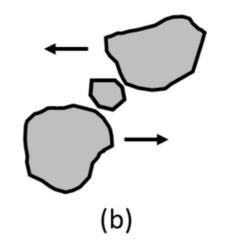

(b)

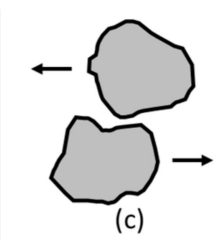

(c)

Figure 1. Grinding mechanisms: (a) compression, (b) chipping, (c) abrasion (adapted from Wills and Finch 2015 [27]).

The forces acting in a tumbling mill can be controlled by varying the operating rotational speed. High rotational speeds are associated with impact and compression forces, generated by particles that are cataracting and cascading (Figure 2).

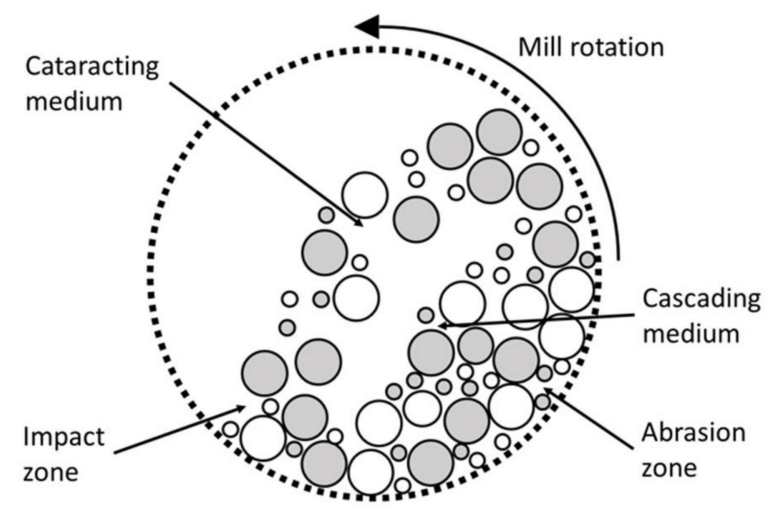

Figure 2. Aggregate motion in a tumbling mill (adapted from Ali et al., 2019 [28]; Wills 2016 [29]; Wills and Finch 2015 [27]).

Alternatively, abrasion is promoted, operating at rotational speeds below $30 \%$ of the critical speed Cs, above which particles are only centrifuged without being ground [30]. For low rotational speeds, particles slide on the drum surface remaining in the abrasion zone (Table 1).

Table 1. Empirical description of the grinding actions at different percentages of $C_{s}$. Numbers from 1 to 3 indicate the ascending degree of action (adapted from Gupta and Yan 2016 [30]).

\begin{tabular}{cccc}
\hline$\% \mathbf{C}_{\mathbf{s}}$ & Sliding & Cascading & Centrifuging \\
\hline $10 \%$ & 3 & - & - \\
$20 \%$ & 3 & - & - \\
$30 \%$ & 3 & 1 & - \\
$40 \%$ & 2 & 1 & - \\
$50 \%$ & 2 & 1 & 1 \\
$60 \%$ & 2 & 2 & 1 \\
$70 \%$ & 1 & 3 & 3 \\
$80 \%$ & 1 & 3 & 2 \\
$90 \%$ & - & 2 & 3 \\
\hline
\end{tabular}

Consequently, the dry treatment process presented in this work did not rely simply on dissolution and mass transfer, which divert the contaminants to wastewater in need of further treatment (as in wet processes); instead, it took advantage of the natural abrasive 
behavior of BA particles, which scrub off each other's external contamination. Moreover, abrasion allows BA particles to preserve their original size, and therefore remain suitable for recycling as secondary aggregates. The output streams of the treatment investigated in this study were a cleansed coarse fraction of inert material and a fine fraction easily removable by sieving. In particular, the intensity of the abrasion process was controlled to limit its effect on the superficial abrasion of the particles' external layers, avoiding comminution and subsequently, particle-size reduction. This work was aimed at exploring the feasibility of a dry abrasion treatment for the reduction of the BA leaching potential for salts and contaminants, in the light of BA reuse as building materials. Furthermore, the effect of the applied treatment was assessed, comparing the leaching behaviors of treated and untreated BA samples. This approach was an advancement with regard to the current industrial trends, where there is no industrial alternative to the wet treatment of BA. To our knowledge, there are still no literature studies investigating abrasion processes applied to BA at the laboratory scale. The work in the present study was performed with batch experiments only within a laboratory setting. However, tumbling mills were applied in the comminution process of ores in continuous operation mode with throughputs in the range of thousands $\mathrm{t} / \mathrm{h}$ [27]. In industrial processing plants, it is possible to increase the residence time in abrasion units, as well as install liners on the inner surface of rotating trommels in order to decrease the dimension of the processing unit and optimize its filling ratio.

\section{Materials and Methods}

\subsection{Origin of the Samples}

This research is part of the activities of the BASH-TREAT "Bottom ash treatment for an improved recovery of valuable fractions" project (ID-157), funded by ERA-NET Cofund in the 2017 call ERA-MIN2 "Research and Innovation Programme on Raw Materials to foster Circular Economy". Specifically, this research considered the valorization of the mineral fraction derived from state-of-the-art BA treatment. The samples of BA mineral fractions were collected from two BA treatment plants located in Germany (Plant A) and Sweden (Plant B). The primary focus of both plants was the recovery of ferrous and non-ferrous metals. In these plants, BA is usually stored for 12 weeks before being processed, in order to decrease the moisture content to values compatible with the adopted technologies. Plant A discharges the fines $(<2 \mathrm{~mm})$ and produces two coarse mineral fractions $(2-8 \mathrm{~mm}$ and $8-40 \mathrm{~mm}$ ), which, for this study, were mixed in homogeneous proportions ( $38 \mathrm{wt} \%$ and $62 \mathrm{wt} \%$, respectively) based on what happened in the plant. Plant B produces a mineral fraction with dimensions in the range $4-26 \mathrm{~mm}$. For this study, 15 incremental samples were collected in each plant, directly at the conveyor belt discharge (sampling the entire section of the belt). The 15 samples were collected at regular intervals within one working day, and later merged into a single composite sample for each plant.

For the abrasion experiments, the mixture $2-40 \mathrm{~mm}$ for Plant $\mathrm{A}$ and the $4-26 \mathrm{~mm}$ fraction for Plant $B$ were further investigated. The fines $(0-2 \mathrm{~mm}$ for Plant $A, 0-4 \mathrm{~mm}$ for Plant B) were not included in the abrasion tests since these fractions were not relevant for their potential reuse as mineral aggregates, and due to the presence of contaminants in high concentrations.

\subsection{Abrasion Tests}

The samples 2-40 mm (from Plant A) and 4-26 mm (from Plant B) underwent the abrasion tests. Two different pilot-scale rotating units were operated with increasing processing times to establish intense abrasion forces. Firstly, an initial abrasion test was performed for $240 \mathrm{~min}$ using a concrete mixer with an inner radius of $50 \mathrm{~cm}$ and a height of $60 \mathrm{~cm}$. The use of a concrete mixer did not allow the removal of fine particles, while minimal losses of fugitive dust from the main opening occurred. Hence, a second abrasion unit was developed, including a sieving device able to remove the fine materials gradually produced. A cylindrical sieving drum (Scheppach RS 400), was coated with a $2 \mathrm{~mm}$ mesh stainless steel grate. The fines produced were collected directly at the bottom of the 
cylindrical drum for further analysis and characterization. The feedstock (12-14 kg) and the rotational speed (set at $42 \mathrm{rpm}$ ) were chosen to avoid the cascading of particles. The abrasion process was investigated by varying the abrasion time (60 and $120 \mathrm{~min}$ ) (Table 2). For all the experiments, the mass and moisture of the samples before and after abrasion were evaluated in order to estimate the production of fines, loss of materials (fugitive dust), and water content. No grinding aids (e.g., steel balls or rods) were added in any of the experiments in order to achieve an autogenous grinding regime [31].

Table 2. Parameters of the abrasion tests performed on the samples collected at plants A and B.

\begin{tabular}{ccccc}
\hline Sample ID & Processing Unit & $\begin{array}{c}\text { Duration } \\
\text { (min) }\end{array}$ & $\begin{array}{c}\text { Plant A } \\
\text { (2-40 mm) }\end{array}$ & $\begin{array}{c}\text { Plant B } \\
\text { (4-26 } \mathbf{~ m m})\end{array}$ \\
\hline Raw & Untreated sample & - & $\checkmark$ & $\checkmark$ \\
CM & Concrete Mixer & 240 & $\boldsymbol{}$ & $\checkmark$ \\
Abr. 60 & Sieving drum & 60 & $\checkmark$ & $\checkmark$ \\
Abr. 120 & Sieving drum & 120 & $\checkmark$ & $\checkmark$ \\
\hline
\end{tabular}

\subsection{Leaching Tests}

Column leaching tests were performed to evaluate the cumulated release of salts and PTEs before and after abrasion, at liquid to solid (L/S) ratio values equal to $0.3,1,2,3$, and $4.0 \mathrm{~L} / \mathrm{kg}$. For each sample, the tests were performed in triplicates. The columns $(40 \mathrm{~cm}$ height, $10 \mathrm{~mm}$ internal diameter) were packed with undried samples, and quartz sand was placed on the top and bottom layers of the column ( $2 \mathrm{~mm}$ thickness, grain size: $0.7-1.2 \mathrm{~mm}$ ). After the saturation of the column, percolation speed was increased according to DIN 19528 [32]. Approximately 3.5-4 kg of the sample was used for each column. The leachates were collected in closed glass bottles for further analyses. For each element, the released amount $\mathrm{E}_{\mathrm{i}}$ at any $\mathrm{L} / \mathrm{S}$ value was calculated (Equation (1)):

$$
\mathrm{E}_{\mathrm{i}}=\left(\mathrm{c}_{\mathrm{i}} \times \mathrm{V}_{\mathrm{i}}\right) / \mathrm{m}_{\mathrm{d}}(\mathrm{mg} / \mathrm{kg})
$$

where $i$ is the index of the eluted fraction $(0.3,1,2,3$, and $4 \mathrm{~L} / \mathrm{kg}) ; \mathrm{c}_{\mathrm{i}}$ is the concentration (in $\mathrm{mg} / \mathrm{L}$ ) of the respective element in the leachate volume $\mathrm{V}_{\mathrm{i}}$ (in litres); $\mathrm{m}_{\mathrm{d}}$ (in $\mathrm{kg}$ ) is the dry mass of the sample in the column. The cumulative leached amount $U$ (with $U_{L / S}=\Sigma E_{i}$, in $\mathrm{mg} / \mathrm{kg}$ ) for each element was given at $\mathrm{L} / \mathrm{S}$ values of 2 and $4 \mathrm{~L} / \mathrm{kg}$ (Equations (2) and (3)).

$$
\begin{gathered}
\mathrm{U}_{\mathrm{L} / \mathrm{S}=2}=\mathrm{E}_{0.3}+\mathrm{E}_{1}+\mathrm{E}_{2} \\
\mathrm{U}_{\mathrm{L} / \mathrm{S}=4}=\mathrm{E}_{0.3}+\mathrm{E}_{1}+\mathrm{E}_{2}+\mathrm{E}_{3}+\mathrm{E}_{4}
\end{gathered}
$$

\subsection{Analytical Procedures}

The moisture content was evaluated on each BA mineral fraction sample by drying batches of materials in porcelain containers at $105^{\circ} \mathrm{C}$, according to DIN EN ISO 17829-1 [33]. The particle size distribution analysis was performed on ash samples before and after the abrasion experiments using a vibratory sieve shaker (Retsch AS 300 control), according to DIN EN 933-1 [34], without any wet removal of the fines.

The procedures adopted to analyze the leachates from the percolation leaching tests were as follows: Immediately after collecting each sample, the electrical conductivity (EC) was measured through a WTW Multi 3320 portable probe. Chlorides were analyzed by titration, following the DIN 38405-1 [35]. Dissolved organic carbon (DOC) was measured through a Multi N/C 2000 analyzer from Analytik Jena AG. Sulphates were analyzed through a Hach DR3900 spectrophotometer. For major elements and PTEs analyses (Ca, K, $\mathrm{Na}, \mathrm{Al}, \mathrm{B}, \mathrm{Ba}, \mathrm{Co}, \mathrm{Cr}, \mathrm{Cu}, \mathrm{Fe}, \mathrm{Li}, \mathrm{Mg}, \mathrm{Mn}, \mathrm{Mo}, \mathrm{Ni}, \mathrm{Sr}, \mathrm{Ti}, \mathrm{V}, \mathrm{Zr}$ ), a part of the leachates was acidified with a small addition (1:100) of $65 \%$ nitric acid and analyzed through an ICP-OES Agilent 5100 spectrometer. All analyses were performed in triplicates. 


\subsection{Data Analysis}

The experimental results derived from the analyses of the leachates that came from the column leaching tests were analyzed though a Pearson correlation analysis (two-tailed, 95\% confidence) by means of the SPSS Statistics software. The Pearson correlation considered a significance level of $\alpha \leq 0.05$.

\section{Results}

\subsection{Physical Characterization}

The particle-size distributions of the BA mineral fraction samples (Figure 3a) were rather different; the samples collected at Plant A presented lower amounts of coarse particles compared to samples from Plant $\mathrm{B}$, although obtaining a greater standard deviation. Considering the particle-size distribution after the abrasion tests (Figure $3 b, c)$, it is possible to observe that, despite the differences between the raw samples, the particle size distribution of the treated samples assumed a coherent behavior, following a narrow bundle where about $25 \%$ of the particles had a dimension of below $6.3 \mathrm{~mm}$. For Plant A the additional fine fraction produced was $25 \%$ and $38 \%$ of the input after $60 \mathrm{~min}$ and $120 \mathrm{~min}$ abrasion, respectively. For Plant B, the fines produced were $12 \%$ and $16 \%$ after $60 \mathrm{~min}$ and $120 \mathrm{~min}$ abrasion, respectively. The significant difference between the processes performed in the two plants was explained by the presence of near-size particles in the Plant A sample, in the fraction proximate to $2 \mathrm{~mm}$ (Plant A range: $2-40 \mathrm{~mm}$ ); however, these were absent in Plant B (range: 4-26 mm). The future optimization of the abrasion process should consider the use of a smaller screen mesh to prevent the loss of particles slightly bigger than $2 \mathrm{~mm}$, together with the abrasion products. Alternatively, the feedstock must be screened to avoid the presence of near-size particles (as occurred naturally for the Plant B material).

$\square$ Plant A $\triangle$ Plant B

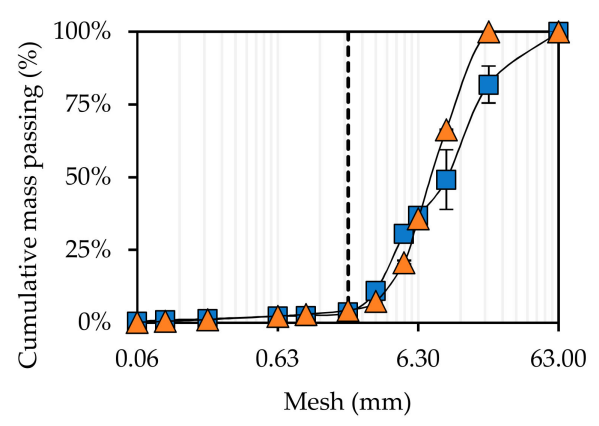

(a)

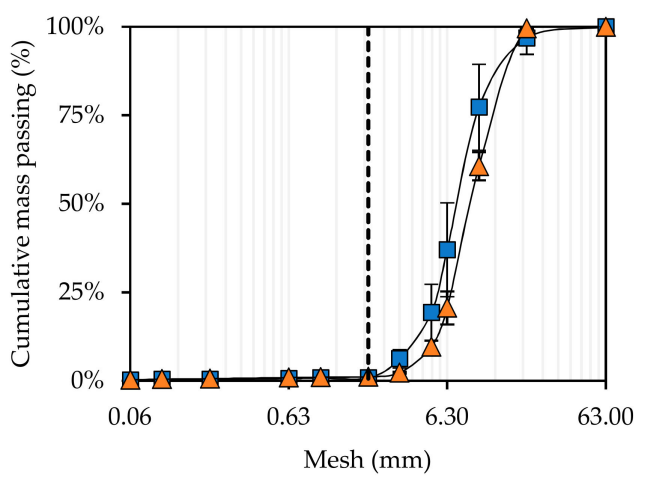

(b)

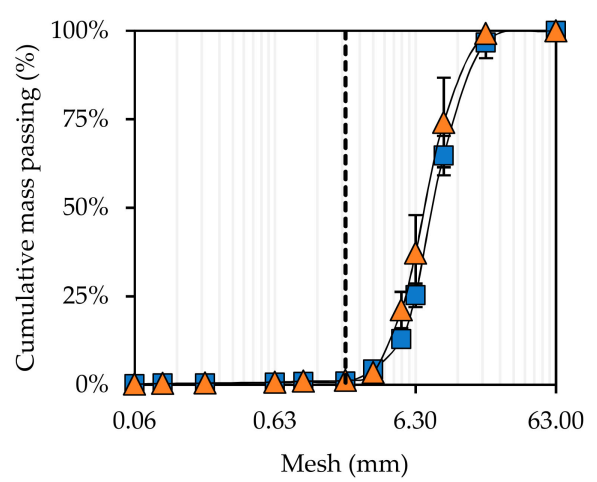

(c)

Figure 3. Particle size distribution of (a) the raw samples from Plant A and Plant B, of (b) samples treated for 60 min and of (c) samples treated for $120 \mathrm{~min}$. Dotted line is mesh $=2 \mathrm{~mm}$. 
The moisture content decreased drastically in the samples processed with the abrasion unit with removal of the fine particles. Considering the samples from Plant $A$, the initial moisture was $7.8 \%$, decreased to $4.2 \%$ after 60 min of abrasion, and further diminished to $2.8 \%$ after 120 min of abrasion. Similarly, for the samples from Plant B, the initial moisture was $4.8 \%$, while the material abraded with the concrete mixer showed a moisture of $4.1 \%$. The moisture was further decreased to 3.3\% and 2.1\% after $60 \mathrm{~min}$ and $120 \mathrm{~min}$ abrasion times, respectively (Figure 4 ). In both samples a limited decrease in the $\mathrm{d}_{50}$ after abrasion can be observed: in plant $A, d_{50}$ decreased from $10.25 \mathrm{~mm}$ to $8.62 \mathrm{~mm}$ after 120 min of abrasion ( $-16 \%$ ), while in plant $\mathrm{B}, \mathrm{d}_{50}$ decreased from $8.03 \mathrm{~mm}$ to $7.58 \mathrm{~mm}$ after the same abrasion time $(-6 \%)$.

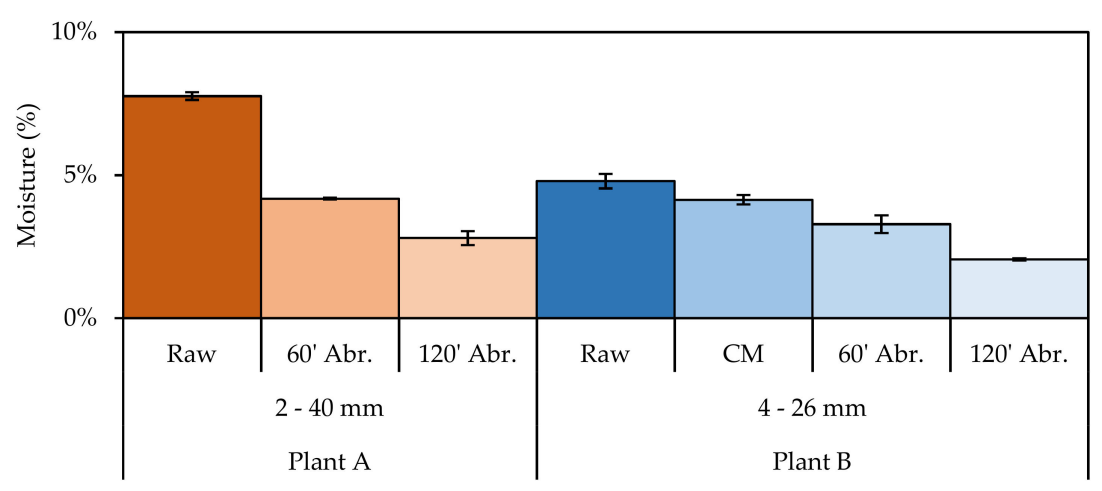

Figure 4. Moisture content of the raw samples from Plant A and Plant $B$, of the samples treated for 60 and 120 min abrasion (Abr.) time, and those treated with the concrete mixer (only Plant B).

\subsection{Leaching Tests}

The performance of the investigated abrasion process was estimated by comparing the results of column leaching tests prior to and after treatment, and by analyzing the release of major salts and PTEs.

\subsubsection{Release of Major Salts}

The purpose of the developed process was to promote the mutual friction between the ash particles. The abrasion, combined with the prompt removal of progressively generated fines and dust, led to a qualitative improvement of the particles' aspect and leaching potential. The intense abrasive forces in the abrasion units were capable of mechanically removing the outer shells of the particles by both smoothing and sanding the ash surfaces. Furthermore, it was suspected that a further contribution to the improvement of the leaching potential could be obtained by the detachment of unbound fine particles weakly adhering to coarser ash fractions, and therefore not screened in standard screening operations in BA processing plants.

The greyish coating layer observed for wet-quenched BA after ageing was removed, displaying the original colors of melt products and inert particles. Specifically, melt products were turned to their original dark brown color and in several cases, their vesicular structure was revealed. It was presumable that repeated collisions cause particle vibrations, in turn capable of detaching mineral phases contained in the ash pores, which are later removed from the process by the continuous turning of the particles. At the same time, refractory materials such as glass, ceramics, and the few metal particles still embedded in the mineral fraction were polished and freed from secondary weathering phases. Therefore, the reduction of salts and PTEs was finally achieved by the sieving out of the progressively generated products of abrasion from the treated coarser particles.

From a qualitative point of view, the removal of the coating layer from BA particles was echoed in an important change in their physical-chemical properties. In all cases, the abraded samples showed a significant decrease in the EC of the leachates (Table 3), which improved with growing abrasion times. Plant A leachates at L/S equal to $0.3 \mathrm{~L} / \mathrm{kg}$ were characterized by EC values at around $20 \mathrm{mS} / \mathrm{cm}$; the EC value halved at $\mathrm{L} / \mathrm{S}$ ratio equal to 
$1 \mathrm{~L} / \mathrm{kg}$, and decreased to values below $2 \mathrm{mS} / \mathrm{cm}$ for $\mathrm{L} / \mathrm{S}$ ratios over $3 \mathrm{~L} / \mathrm{kg}$. Regarding $60 \mathrm{~min}$ and $120 \mathrm{~min}$ abrasion times, it was possible to observe a reduction of $30 \%$ and $66 \%$ on the initial EC, decreased down to values below $1 \mathrm{mS} / \mathrm{cm}$ for L/S ratio equal to $4 \mathrm{~L} / \mathrm{kg}$. Similar results were achieved for the leachates of the samples from Plant B; the EC of the untreated samples was lower compared to that of the samples from Plant A $(7 \mathrm{mS} / \mathrm{cm})$, with the EC value almost halved after $120 \mathrm{~min}$ of abrasion time. Even in this case, the final EC values were below $1 \mathrm{mS} / \mathrm{cm}$ for $\mathrm{L} / \mathrm{S}$ equal to $4 \mathrm{~L} / \mathrm{kg}$. The analysis of the EC trends clearly demonstrated a significant depletion of the soluble species in the treated BA samples. Linear correlations between EC values and the concentrations of the main salts in the leachates were proven (Figure 5). This, in turn, could be directly correlated with a significant reduction of chloride $(\mathrm{r}(58)=0.98, p<0.01)$ and sulphate $(\mathrm{r}(58)=0.94, p<0.01)$ concentrations. Thus, the EC could be used as a quick in-field control parameter for the evaluation of the effectiveness of an abrasion process.

Table 3. Electrical conductivity values measured in leachates, obtained at different L/S ratios. (Raw: untreated sample; 240 CM: samples treated in the concrete mixer for 240 min; 60-120 Abr.: samples treated in the sieving drum for 60 and $120 \mathrm{~min}$ abrasion (Abr.) time respectively).

\begin{tabular}{|c|c|c|c|c|c|}
\hline $\begin{array}{c}\mathrm{L} / \mathrm{S} \\
(\mathrm{L} / \mathrm{kg})\end{array}$ & Raw & $240 \mathrm{CM}$ & $\begin{array}{l}\text { Plant A } \\
(\mathrm{mS} / \mathrm{cm})\end{array}$ & Abr. 60 & Abr. 120 \\
\hline $\begin{array}{l}0.3 \\
1.0 \\
2.0 \\
3.0 \\
4.0\end{array}$ & $\begin{array}{c}19.53 \pm 0.31 \\
9.63 \pm 1.87 \\
3.35 \pm 0.13 \\
2.03 \pm 0.07 \\
1.53 \pm 0.07\end{array}$ & $\begin{array}{c}\text { Not } \\
\text { investigated }\end{array}$ & & $\begin{array}{c}13.31 \pm 0.54 \\
5.27 \pm 0.57 \\
2.47 \pm 0.37 \\
1.38 \pm 0.10 \\
0.93 \pm 0.03\end{array}$ & $\begin{array}{l}6.64 \pm 0.30 \\
3.64 \pm 0.12 \\
1.72 \pm 0.10 \\
1.03 \pm 0.03 \\
0.73 \pm 0.01\end{array}$ \\
\hline $\begin{array}{c}\mathrm{L} / \mathrm{S} \\
(\mathrm{L} / \mathrm{kg})\end{array}$ & Raw & $240 \mathrm{CM}$ & $\begin{array}{l}\text { Plant B } \\
(\mathrm{mS} / \mathrm{cm})\end{array}$ & Abr. 60 & Abr. 120 \\
\hline $\begin{array}{l}0.3 \\
1.0 \\
2.0 \\
3.0 \\
4.0\end{array}$ & $\begin{array}{l}7.08 \pm 1.24 \\
3.19 \pm 0.35 \\
1.85 \pm 0.12 \\
1.35 \pm 0.08 \\
1.18 \pm 0.06\end{array}$ & $\begin{array}{l}7.40 \pm 1.59 \\
3.73 \pm 0.29 \\
2.00 \pm 0.17 \\
1.24 \pm 0.12 \\
1.07 \pm 0.12\end{array}$ & & $\begin{array}{l}4.50 \pm 0.35 \\
2.97 \pm 0.16 \\
1.56 \pm 0.07 \\
1.02 \pm 0.02 \\
0.86 \pm 0.19\end{array}$ & $\begin{array}{l}3.88 \pm 0.22 \\
2.77 \pm 0.27 \\
1.37 \pm 0.04 \\
1.10 \pm 0.04 \\
0.63 \pm 0.03\end{array}$ \\
\hline
\end{tabular}

$\square$ Plant A $\triangle$ Plant B

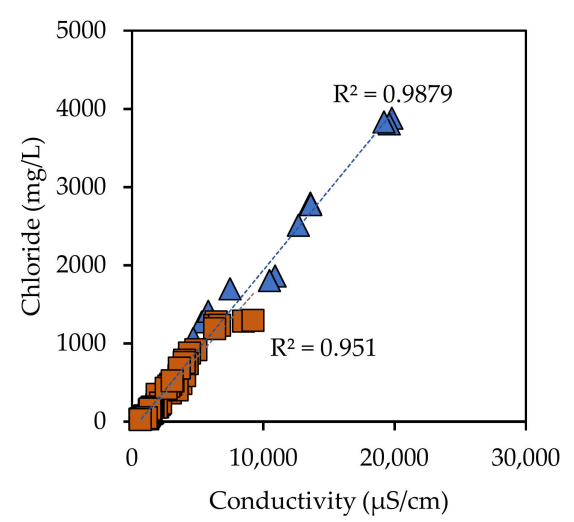

(a)

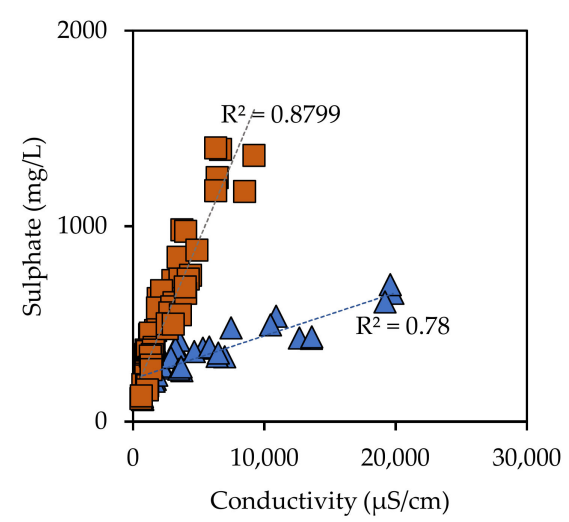

(b)

Figure 5. Correlations between electrical conductivity and (a) chloride and (b) sulphate concentrations in the leachates.

The cumulative releases of chloride and sulphate ions in the leachates before and after the abrasion tests are shown in Figure 6 and in Table 4. Chloride salts, which are highly soluble, exhibited leaching profiles characterized by a relevant drop in concentrations that are already at low $\mathrm{L} / \mathrm{S}$ ratios. With regard to the samples from Plant $\mathrm{A}$, the unprocessed BA presented initial chloride concentrations close to $3800 \mathrm{mg} / \mathrm{L}$ at an $\mathrm{L} / \mathrm{S}$ ratio of $0.3 \mathrm{~L} / \mathrm{kg}$ 
(Figure 6a). These values were halved at an L/S ratio equal to 1 due to the high solubility of chlorides. Between $\mathrm{L} / \mathrm{S}$ ratios equal to 1 and $2 \mathrm{~L} / \mathrm{kg}$, it was possible to observe the shift from the diffusion-controlled dissolution to the reaction-controlled dissolution of lowsolubility mineral chloride phases. This was clearly visible in the cumulative concentration curve of chlorides, which tends to flatten for $\mathrm{L} / \mathrm{S}$ ratios $>2 \mathrm{~L} / \mathrm{kg}$. Regarding the samples from Plant $B$, the processed samples showed decreasing initial chloride concentrations for growing abrasion times (Figure $6 \mathrm{c}$ ). The effect of the abrasion was reflected mostly at low $\mathrm{L} / \mathrm{S}$ ratios, where concentrations of $2700 \mathrm{mg} \mathrm{Cl}^{-} / \mathrm{L}$ and $1800 \mathrm{mg} \mathrm{Cl}^{-} / \mathrm{L}$ were observed at an $\mathrm{L} / \mathrm{S}$ ratio of $0.3 \mathrm{~L} / \mathrm{kg}$, for $60 \mathrm{~min}$ and $120 \mathrm{~min}$ of abrasion time, respectively. This results in the flattening of the cumulative release profile at an L/S ratio equal to $1 \mathrm{~L} / \mathrm{kg}$, and the cumulative release limited to $2300 \mathrm{mg} / \mathrm{kg}$ and $1600 \mathrm{mg} / \mathrm{kg}$ for $60 \mathrm{~min}$ and 120 min of abrasion time, respectively. Similar behaviour was observed for the samples from Plant B. In this case, the unprocessed ash and the samples abraded in the concrete mixer showed comparable results. This could be attributed to the establishment of adhesive electrostatic forces between the fine material not promptly removed from the processing unit and the coarse aggregates. However, the concrete mixer abrasion unit was not further investigated. On the other hand, the cumulative chloride release at an L/S equal to $4 \mathrm{~L} / \mathrm{kg}$ showed a reduction in the total released chlorides for the treated samples. This resulted in a depletion from circa $1050 \mathrm{mg} \mathrm{Cl}^{-} / \mathrm{kg}$ for raw BA from Plant $\mathrm{B}$, to 870 and $770 \mathrm{mg} \mathrm{Cl}^{-} / \mathrm{kg}$ after $60 \mathrm{~min}$ and $120 \mathrm{~min}$ of abrasion time, respectively.

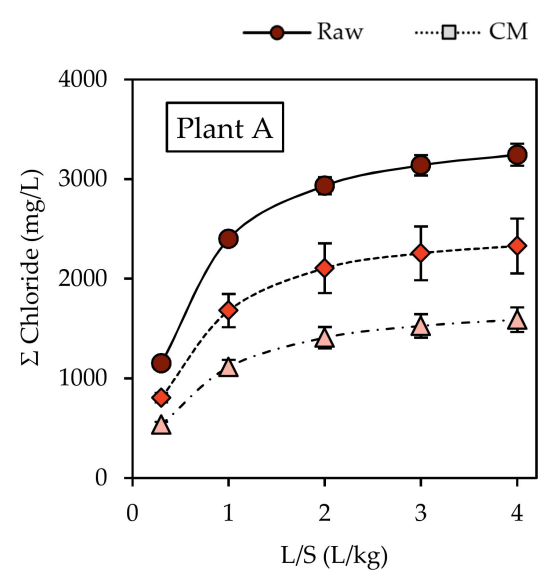

(a)

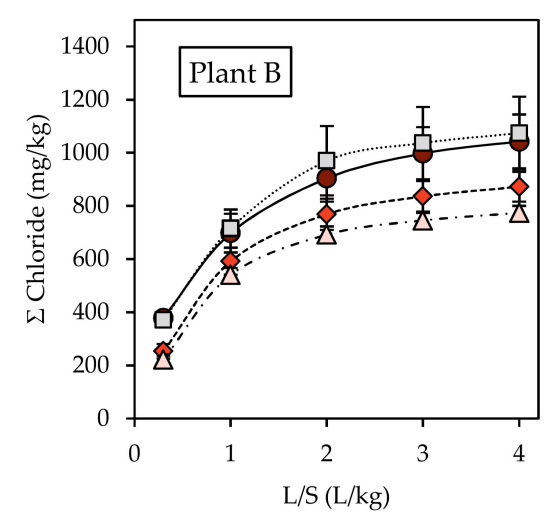

(c)

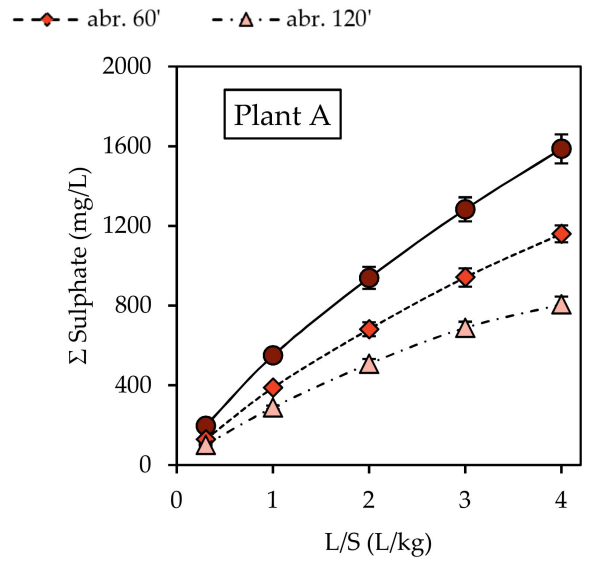

(b)

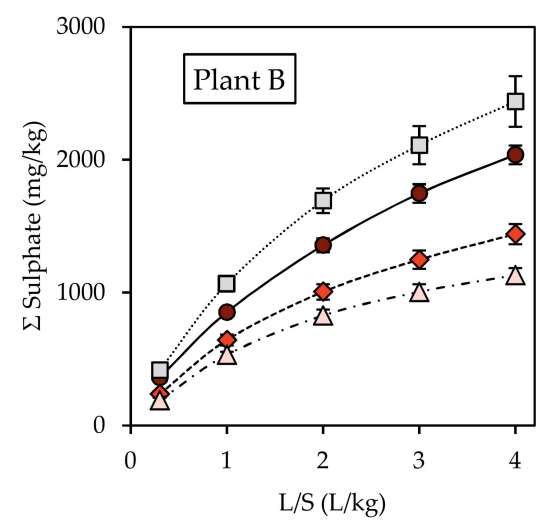

(d)

Figure 6. Trends of (a) chlorides and (b) sulphates' cumulative release from the raw BA samples, and of (c) chlorides and (d) sulphates' cumulative release after the abrasion tests (raw: untreated samples; CM: samples treated in the concrete mixer for $240 \mathrm{~min}$; abr. 60 and abr. 120: samples treated in the sieving drum unit for $60 \mathrm{~min}$ and $120 \mathrm{~min}$ ). 
Table 4. Cumulative release for the elements considered at an L/S equal to $4 \mathrm{~L} / \mathrm{kg}$. (The results obtained from the concrete mixer are not shown). Reduction rates are calculated on the raw sample for increasing abrasion (Abr.) times.

\begin{tabular}{|c|c|c|c|c|c|c|c|c|c|c|}
\hline \multirow{3}{*}{ Parameter } & \multicolumn{5}{|c|}{ Plant A } & \multicolumn{5}{|c|}{ Plant B } \\
\hline & \multicolumn{3}{|c|}{ Concentration } & \multicolumn{2}{|c|}{ Reduction Rate } & \multicolumn{3}{|c|}{ Concentration } & \multicolumn{2}{|c|}{ Reduction Rate } \\
\hline & Raw & Abr. $60^{\prime}$ & Abr. $120^{\prime}$ & Abr. $60^{\prime}$ & Abr. $120^{\prime}$ & Raw & Abr. $60^{\prime}$ & Abr. 120' & Abr. $60^{\prime}$ & Abr. 120 \\
\hline \multicolumn{11}{|c|}{ Major Elements (mg/kg) } \\
\hline $\mathrm{Cl}^{-}$ & $3244 \pm 111$ & $2329 \pm 275$ & $1589 \pm 123$ & $-28 \%$ & $-51 \%$ & $1043 \pm 102$ & $872 \pm 56$ & $774 \pm 27$ & $-16 \%$ & $-26 \%$ \\
\hline $\mathrm{SO}_{4}^{2-}$ & $1587 \pm 73$ & $1160 \pm 42$ & $806 \pm 39$ & $-27 \%$ & $-49 \%$ & $2037 \pm 70$ & $1441 \pm 76$ & $1132 \pm 54$ & $-29 \%$ & $-44 \%$ \\
\hline DOC & $264 \pm 16$ & $180 \pm 11$ & $120 \pm 9$ & $-32 \%$ & $-55 \%$ & $157 \pm 24$ & $117 \pm 3$ & $96 \pm 5$ & $-26 \%$ & $-39 \%$ \\
\hline $\mathrm{Ca}$ & $1360 \pm 134$ & $887 \pm 33$ & $668 \pm 23$ & $-35 \%$ & $-51 \%$ & $529 \pm 29$ & $404 \pm 16$ & $325 \pm 8$ & $-24 \%$ & $-39 \%$ \\
\hline K & $627 \pm 19$ & $454 \pm 36$ & $345 \pm 20$ & $-27 \%$ & $-45 \%$ & $249 \pm 21$ & $203 \pm 11$ & $176 \pm 7$ & $-19 \%$ & $-29 \%$ \\
\hline $\mathrm{Na}$ & $1224 \pm 33$ & $912 \pm 78$ & $711 \pm 46$ & $-25 \%$ & $-42 \%$ & $834 \pm 80$ & $674 \pm 45$ & $587 \pm 33$ & $-19 \%$ & $-30 \%$ \\
\hline \multicolumn{11}{|c|}{ Minor Elements $(\mu \mathrm{g} / \mathrm{kg})$} \\
\hline Al & $3913 \pm 769$ & $\begin{array}{c}9822 \pm \\
1267\end{array}$ & $\begin{array}{c}17290 \pm \\
4085\end{array}$ & $151 \%$ & $342 \%$ & $7222 \pm 521$ & $6192 \pm 167$ & $5964 \pm 195$ & $-14 \%$ & $-17 \%$ \\
\hline B & $495 \pm 126$ & $373 \pm 13$ & $698 \pm 167$ & $-25 \%$ & $41 \%$ & $1891 \pm 124$ & $1593 \pm 51$ & $1815 \pm 228$ & $-16 \%$ & $-4 \%$ \\
\hline Ba & $639 \pm 62$ & $557 \pm 15$ & $476 \pm 28$ & $-13 \%$ & $-25 \%$ & $220 \pm 9$ & $219 \pm 12$ & $206 \pm 5$ & $-1 \%$ & $-7 \%$ \\
\hline Co & $11 \pm 4$ & $16 \pm 2$ & $18 \pm 3$ & $44 \%$ & $55 \%$ & $37 \pm 4$ & $49 \pm 11$ & $57 \pm 3$ & $33 \%$ & $52 \%$ \\
\hline $\mathrm{Cr}$ & $276 \pm 45$ & $152 \pm 17$ & $141 \pm 15$ & $-45 \%$ & $-49 \%$ & $469 \pm 76$ & $290 \pm 67$ & $221 \pm 43$ & $-38 \%$ & $-53 \%$ \\
\hline $\mathrm{Cu}$ & $1613 \pm 76$ & $868 \pm 61$ & $619 \pm 135$ & $-46 \%$ & $-62 \%$ & $448 \pm 118$ & $301 \pm 172$ & $181 \pm 31$ & $-33 \%$ & $-60 \%$ \\
\hline $\mathrm{Fe}$ & $181 \pm 65$ & $206 \pm 41$ & $216 \pm 42$ & $14 \%$ & $19 \%$ & $323 \pm 83$ & $245 \pm 19$ & $316 \pm 49$ & $-24 \%$ & $-2 \%$ \\
\hline $\mathrm{Li}$ & $500 \pm 42$ & $285 \pm 17$ & $184 \pm 4$ & $-43 \%$ & $-63 \%$ & $94 \pm 8$ & $56 \pm 6$ & $40 \pm 6$ & $-41 \%$ & $-58 \%$ \\
\hline $\mathrm{Mg}$ & $351 \pm 54$ & $337 \pm 8$ & $460 \pm 44$ & $-4 \%$ & $31 \%$ & $347 \pm 36$ & $284 \pm 53$ & $337 \pm 21$ & $-18 \%$ & $-3 \%$ \\
\hline Mn & $9 \pm 1$ & $13 \pm 2$ & $10 \pm 2$ & $40 \%$ & $6 \%$ & $20 \pm 3$ & $18 \pm 3$ & $22 \pm 2$ & $-10 \%$ & $10 \%$ \\
\hline Mo & $586 \pm 14$ & $498 \pm 19$ & $440 \pm 14$ & $-15 \%$ & $-25 \%$ & $400 \pm 18$ & $375 \pm 46$ & $368 \pm 39$ & $-6 \%$ & $-8 \%$ \\
\hline $\mathrm{Ni}$ & $38 \pm 16$ & $27 \pm 17$ & $30 \pm 4$ & $-28 \%$ & $-21 \%$ & $67 \pm 14$ & $96 \pm 17$ & $104 \pm 15$ & $43 \%$ & $54 \%$ \\
\hline Sr & $8528 \pm 700$ & $5552 \pm 263$ & $3589 \pm 39$ & $-35 \%$ & $-58 \%$ & $1955 \pm 89$ & $1555 \pm 118$ & $1208 \pm 38$ & $-20 \%$ & $-38 \%$ \\
\hline $\mathrm{Ti}$ & $45 \pm 1$ & $43 \pm 3$ & $43 \pm 1$ & $-5 \%$ & $-6 \%$ & $99 \pm 1$ & $100 \pm 3$ & $100 \pm 1$ & $1 \%$ & $0 \%$ \\
\hline V & $203 \pm 19$ & $144 \pm 6$ & $126 \pm 9$ & $-29 \%$ & $-38 \%$ & $145 \pm 8$ & $144 \pm 4$ & $143 \pm 5$ & $0 \%$ & $-1 \%$ \\
\hline $\mathrm{Zn}$ & $166 \pm 37$ & $143 \pm 65$ & $110 \pm 33$ & $-14 \%$ & $-34 \%$ & $80 \pm 31$ & $265 \pm 138$ & $20 \pm 1$ & $233 \%$ & $-75 \%$ \\
\hline
\end{tabular}

The sulphates' leaching trends (Figure 6) were slightly different from those of chlorides, exhibiting a slower concentration decay and resulting in an almost linear cumulative release profile. This could be explained by the sparing solubility of sulphate species such as ettringite, which are governed by reaction-controlled dissolution. Hence, considering the samples collected from Plant A, concentrations of sulphates in the leachate derived from the raw samples (Figure $6 \mathrm{~b}$ ) decreased from $650 \mathrm{mg} \mathrm{SO}_{4}{ }^{2-} / \mathrm{L}$ at $\mathrm{L} / \mathrm{S}$ equal to $0.3 \mathrm{~L} / \mathrm{kg}$, down to approximately $300 \mathrm{mg} \mathrm{SO}_{4}{ }^{2-} / \mathrm{L}$ at L/S equal to $4 \mathrm{~L} / \mathrm{kg}$. However, with regard to the samples from Plant $B$, the untreated ones were characterized by higher concentrations of sulphate in leachates (Figure 6d); more specifically, it was possible to observe a leaching profile that shared the features of both the reaction-controlled and diffusion-controlled dissolution of salts. Significant reductions in the concentration of sulphates were observed between L/S 0.3 and $1 \mathrm{~L} / \mathrm{kg}$, probably due to the presence of large amount of sulphate salts. Their depletion occurred especially until $\mathrm{L} / \mathrm{S}$ equal to 1 , after which a constant decrease was observed (Figure 6d). For the treated samples, a reduction in sulphate concentrations with growing abrasion times was observed in all samples. In contrast to the case of chlorides, the flattening of the cumulative release profiles for sulphate was partially appreciable after $120 \mathrm{~min}$ of abrasion time for $\mathrm{L} / \mathrm{S}=4 \mathrm{~L} / \mathrm{kg}$. Regarding the samples from Plant $\mathrm{A}$, the cumulative release decreased from $1600 \mathrm{mg} \mathrm{SO}_{4}{ }^{2-} / \mathrm{L}$ down to around $1150 \mathrm{mg} \mathrm{SO}_{4}{ }^{2-} / \mathrm{L}$ (after $60 \mathrm{~min}$ abrasion) and $800 \mathrm{mg} \mathrm{SO}_{4}{ }^{2-} / \mathrm{L}$ (after $20 \mathrm{~min}$ abrasion). For samples derived from Plant $\mathrm{B}$, the cumulative release of untreated material was over $2000 \mathrm{mg} \mathrm{SO}_{4}{ }^{2-} / \mathrm{L}$ and reduced to $1450 \mathrm{mg} \mathrm{SO}_{4}{ }^{2-} / \mathrm{L}$ and $1150 \mathrm{mg} \mathrm{SO}_{4}{ }^{2-} / \mathrm{L}$ after $60 \mathrm{~min}$ and $120 \mathrm{~min}$ of abrasion times, respectively.

\subsubsection{Release of Other Compounds}

The values for the cumulative release of major and minor elements in the leachates are displayed in Table 4. Chloride and sulphate trends have been previously discussed. The superficial abrasion was demonstrated to be capable of reducing DOC cumulative release to $39 \%$, which is, together with sulphate, the main reason for copper release, as suggested by several studies [36,37] and also confirmed by this work. Despite the high standard deviations obtained by measuring $\mathrm{Cu}$ concentrations in the leachates, the decrease of DOC could be the cause of a drastic reduction in $\mathrm{Cu}$ concentrations. Furthermore, a 
reduction of both $\mathrm{Cu}$ and DOC after the treatment with the concrete mixer was observed (data not shown). This trend was not observed for other elements, suggesting an auxiliary mechanism acting during the abrasion. However, the reduction was expected to be less effective with the extension of the process duration. As mentioned in the introduction, salts and PTEs during ageing acted as a coating layer on BA particles. By extending the abrasion time enough to completely wear out the outer particle shell, surfaces of minerals formed within the incineration chamber and refractory materials started to be abraded. This behavior explained the higher measure of iron and nickel concentrations in the leachates after $120 \mathrm{~min}$ of abrasion time (Table 4). Iron in BA is in the form of non-soluble minerals, and despite its concentration in BA (31-150 g Fe/kg BA) (Astrup et al., 2016), its concentrations in the leachates were relatively low. Hence, what could be hypothesized is that by prolonging the abrasion time, iron minerals start to wear out, leading to increasing iron concentrations in the leachates. As for the main soluble species, the release of specific PTEs as $\mathrm{Cu}, \mathrm{Cr}$, and Mo can be tracked by following the progressive washout of the main salts. Molybdenum present as oxyanion $\mathrm{MoO}_{4}{ }^{2-}$ is reported to exhibit high solubility, although the formation of minerals such as powellite $\left(\mathrm{CaMoO}_{4}\right)$ might have an influence on the leaching behavior [38]. However, in this study, notwithstanding a significant relationship with sulphate concentrations, Mo showed a slightly higher correlation with chloride concentrations ( $\mathrm{r}(58)=0.97, p<0.001)$.

Another important piece of information obtained from exploring the correlations among the different elements is the speciation of the soluble salts. The main chloride forms in $\mathrm{BA}$ are halite $(\mathrm{NaCl})$ and sylvite $(\mathrm{KCl})$ [18]. This was also proven in this work, where the chloride correlations with $\mathrm{K}$ and $\mathrm{Na}$ concentrations in the leachates (detailed in the Supplementary Materials) suggested that halite was the primary cause of chloride release $(\mathrm{Cl}-\mathrm{Na}: \mathrm{r}(58)=0.99, p<0.001 ; \mathrm{Cl}-\mathrm{K}: \mathrm{r}(58)=0.99, p<0.001)$. Similarly, the correlation between calcium and sulphate concentrations $(\mathrm{r}(58)=0.98, p<0.001)$ suggested the dissolution of gypsum, a typical product resulting from BA weathering processes [16].

The efficiency of the proposed dry treatment was finally assessed by studying the correlations between the major elements and the PTEs. The statistical analysis performed on all the concentration values measured in the leachates (Tables S1 and S2, Supplementary Materials) allowed us to obtain some interesting results (Figure 7). Chloride and sulphate concentrations in the leachates showed a good correlation with $\mathrm{Ba}, \mathrm{Cu}, \mathrm{Mo}$, and $\mathrm{Sr}$. It can be concluded that the dissolution trends of the PTEs were coherent with the behavior followed by the bearing salts (e.g., mainly chlorides and sulphates), present in the outer layers coating the BA particles.

The variables portrayed in Figure 7 show a large positive relationship; the values of the coefficient $\mathrm{R}^{2}$ determine the quality of the fitting of the linear correlation model applied to the considered variables. Nonetheless, the strength of the correlation between the variables was expressed by the Pearson coefficient R (see Supplementary Materials Tables S1 and S2). All the portrayed relationships displayed a significance level below the threshold $\alpha \leq 0.05$. 
$\square$ Plant A $\triangle$ Plant B

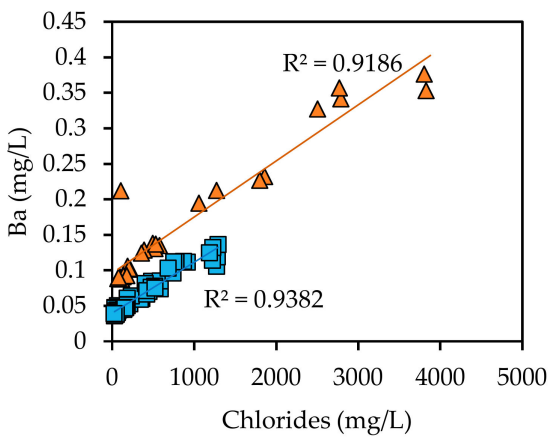

(a1)

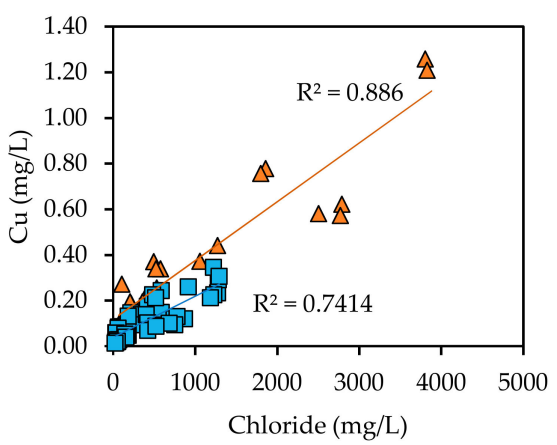

(a2)

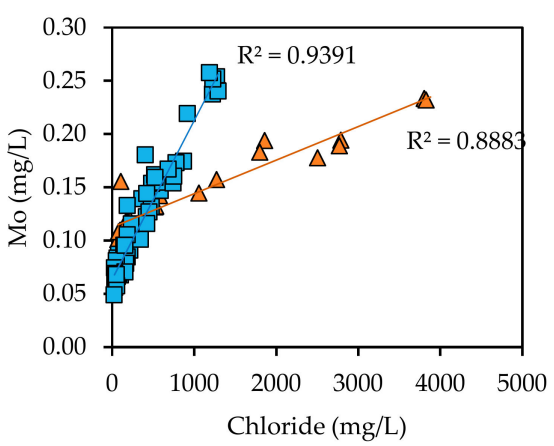

(a3)

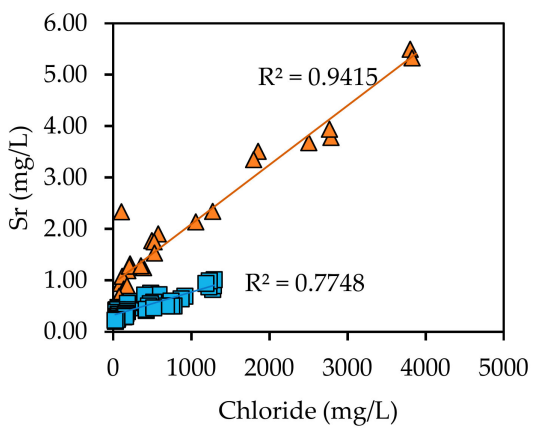

(a4)

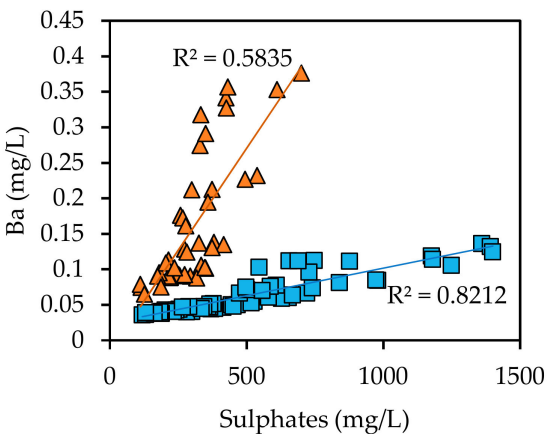

(b1)

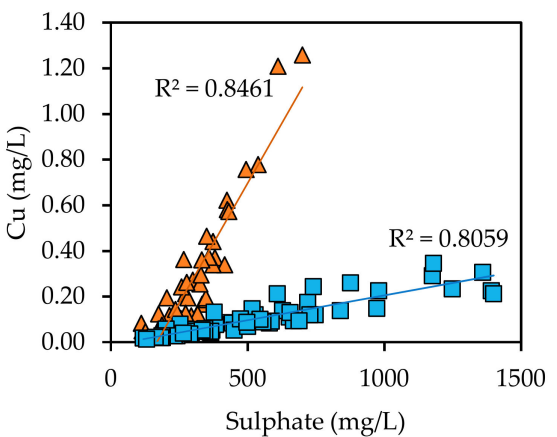

(b2)

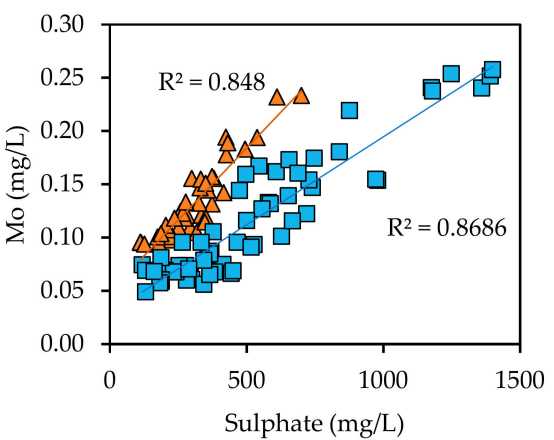

(b3)

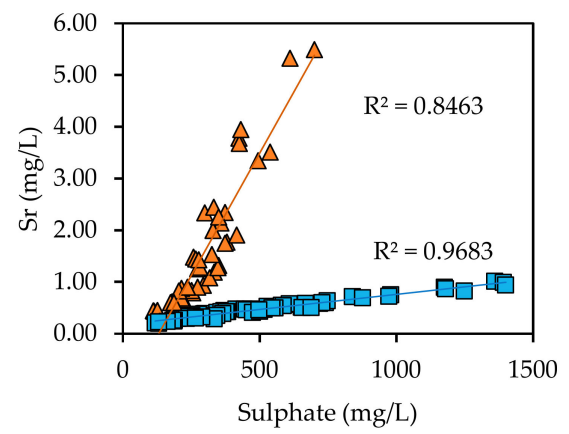

(b4)

Figure 7. Correlations between chlorides (a1-a4) and sulphates (b1-b4) and $\mathrm{Ba}, \mathrm{Cu}, \mathrm{Mo}$, and $\mathrm{Sr}$ in the leachates derived from the column leaching tests. 


\section{Conclusions}

This work investigated at the laboratory scale a dry treatment process based on abrasion, used for the removal of salts and PTEs from BA mineral fraction particles. Two different abrasion units were developed and operated at different times. The best results were obtained using an attrition unit equipped with a screen for the removal of the progressively generated fines. In this case, a relevant drop in the electrical conductivity was associated to a reduction of chlorides (up to $26 \%$ ) and sulphates (up to $44 \%$ ), in turn coherent with lower amounts of PTEs released from BA in percolation tests (up to 53\% for chromium, $60 \%$ for copper, and $8 \%$ for molybdenum). On the other hand, prolonged abrasion times showed slightly higher concentrations of $\mathrm{Fe}, \mathrm{Co}$, and $\mathrm{Ni}$ in leachates, suggesting that the process reached deeper layers of iron-containing incineration products. Further tests are required to assess the release of these metals in aggregate mixtures and its correlation with the duration of abrasion. The statistical analysis revealed good correlations between chloride and sulphate concentrations in the leachates, and the concentrations of barium, copper, molybdenum, and strontium, thus revealing consistent behavior for the major salts and the cited minor components present in the layer surrounding the BA particles. Overall, the studied approach is a valid alternative to wet processes for the reduction of the leaching potential of salts and PTEs in coarse bottom ash samples. However, two key issues need to be further investigated: the specific effect of abrasion on BA components (inerts, refractory materials, and incineration products), and the influence of abrasion on the release of PTEs in the leachates.

The results of our research cannot be compared with previous studies on the topic due to the originality of the process, making it impossible to contextualize our findings. As a general conclusion, any BA valorization strategy should consider that the parent material could affect the overall impact of the results of the abrasion because of two key issues. Firstly, the chemical composition: salts and PTEs, if included in BA composition (e.g., sulphates in residues from renovation activities and/or gypsum), would be released as fine particles. Therefore, it was necessary to equip the abrasion unit with a screen for the removal of fines to limit their recirculation and adhesion to the abraded particles. Secondly, the material hardness: the lower it was, the more effective the abrasion was. Refractory materials (glass, ceramics) and incineration products (silicates/pyroxenes, oxides/spinels, and hematite) commonly found in BA are harder than the weathering phases, making possible their further removal through abrasion. In the absence of these harder fractions, it was predictable that salts and PTEs would land directly with the fines that had already been separated in the BA processing plants.

Supplementary Materials: The following are available online at https:/ / www.mdpi.com/article/10 $.3390 / \mathrm{ma14113133/s1}$, Table S1: Results of statistical analysis of the correlations among the major and minor compounds analysed in the leachates (samples of bottom ash mineral fraction from PLANT A); Table S2: Results of statistical analysis of the correlations among the major and minor compounds analysed in the leachates (samples of bottom ash mineral fraction from PLANT B).

Author Contributions: Conceptualization, methodology, experimental investigation, data curation, writing-original draft preparation, M.A. and M.B.; conceptualization, methodology, supervision, S.F.; writing-review and editing, M.A., M.B., F.-G.S., R.G., M.H., K.K. and S.F.; project administration and funding acquisition, K.K., F.-G.S., R.G., M.H. and S.F. All authors have read and agreed to the published version of the manuscript.

Funding: The authors would like to acknowledge the financial support to the project BASH-Treat (ID 157) provided by the ERA-MIN2 Research \& Innovation Programme on Raw Materials to Foster Circular Economy, by the German Federal Ministry of Education and Research (BMBF, FKZ 033RU005 A-C) and by the Italian Ministry of University and Research (MIUR). The authors are thankful to project partners Heidemann Recycling $\mathrm{GmbH}$ and Sysav Utveckling AB.

Institutional Review Board Statement: Not applicable.

Informed Consent Statement: Not applicable. 
Data Availability Statement: The full data related to this research are not publicly available due to the confidentiality agreement signed by the Consortium of BASH-TREAT project.

Acknowledgments: The authors gratefully acknowledge the support of the "Open access publishing" program of Hamburg University of Technology for part of the article processing fee.

Conflicts of Interest: The authors declare no conflict of interest.

\section{References}

1. British Geological Survey. BGS, British Geological Survey World Mineral Production 2013-2017; British Geological Survey: Nottingham, UK, 2019. Available online: http:/ /www.bgs.ac.uk/mineralsuk/statistics/worldStatistics.html (accessed on 2 June 2020).

2. Publications Office of the European Union. European Commission Study on the Review of the list of Critical Raw Materials. In Non-Critical Raw Materials Factsheets; Publications Office of the European Union: Luxembourg, 2017.

3. Thomé-Kozmiensky, E. Abfallverbrennungsanlagen—Deutschland-2016 | 2017; Thomé-Kozmiensky GmbH (Anlagendokumentation, 2): Nietwerder, Germany, 2018.

4. Neuwahl, F.; Cusano, G.; Benadives, J.G.; Holbrook, S.; Serge, R. Best Available Techniques (BAT) Reference Document for Waste Treatment Industries; Publications Office of the European Union: Luxembourg, 2019. [CrossRef]

5. Astrup, T.; Muntoni, A.; Polettini, A.; Pomi, R.; van Gerven, T.; van Zomeren, A. Chapter 24-Treatment and Reuse of Incineration Bottom Ash. In Environmental Materials and Waste//Environmental Materials and Waste. Resource Recovery and Pollution Prevention; Prasad, M.N.V., Shih, K., Eds.; Academic Press: Cambridge, MA, USA, 2016; pp. 607-645. [CrossRef]

6. Šyc, M.; Simon, F.G.; Hykš, J.; Braga, R.; Biganzoli, L.; Costa, G.; Funari, V.; Grosso, M. Metal recovery from incineration bottom ash: State-of-the-art and recent developments. J. Hazard. Mater. 2020, 393. [CrossRef] [PubMed]

7. van Praagh, M.; Johansson, M.; Fagerqvist, J.; Grönholm, R.; Hansson, N.; Svensson, H. Recycling of MSWI-bottom ash in paved constructions in Sweden-A risk assessment. Waste Manag. 2018, 79, 428-434. [CrossRef] [PubMed]

8. Minane, J.R.; Becquart, F.; Abriak, N.E.; Deboffe, C. Upgraded Mineral Sand Fraction from MSWI Bottom Ash: An Alternative Solution for the Substitution of Natural Aggregates in Concrete Applications. Procedia Eng. 2017, 180, 1213-1220. [CrossRef]

9. Ginés, O.; Chimenos, J.M.; Vizcarro, A.; Formosa, J.; Rosell, J.R. Combined use of MSWI bottom ash and fly ash as aggregate in concrete formulation: Environmental and mechanical considerations. J. Hazard. Mater. 2009, 169, 643-650. [CrossRef] [PubMed]

10. Keulen, A.; van Zomeren, A.; Harpe, P.; Aarnink, W.; Simons, H.A.E.; Brouwers, H.J.H. High performance of treated and washed MSWI bottom ash granulates as natural aggregate replacement within earth-moist concrete. Waste Manag. 2016, 49 , 83-95. [CrossRef] [PubMed]

11. Brown, T.J.; Idoine, N.E.; Wrighton, C.E.; Raycraft, E.R.; Hobbs, S.F.; Shaw, R.A.; Everett, P.; Kresse, C.; Deady, Y.E.A.; Bide, T. World Mineral Production 2014-2018; British Geological Survey: Nottingham, UK, 2016.

12. Blasenbauer, D.; Huber, F.; Lederer, J.; Quina, M.J.; Blanc-Biscarat, D.; Bogush, A.; Bontempi, E.; Blondeau, J.; Chimenos, J.M.; Dahlbo, H.; et al. Legal situation and current practice of waste incineration bottom ash utilisation in Europe. Waste Manag. 2020, 102, 868-883. [CrossRef] [PubMed]

13. Pourret, O.; Bollinger, J.C.; Hursthouse, A. Heavy Metal: A misused term? Acta Geochim. 2021. [CrossRef]

14. Di Gianfilippo, M.; Hyks, J.; Verginelli, I.; Costa, G.; Hjelmar, O.; Lombardi, F. Leaching behaviour of incineration bottom ash in a reuse scenario: 12years-field data vs. lab test results. Waste Manag. 2018, 73, 367-380. [CrossRef]

15. Dijkstra, J.J.; van Zomeren, A.; Meeussen, J.C.L.; Comans, R.N.J. Effect of accelerated aging of MSWI bottom ash on the leaching mechanisms of copper and molybdenum. Environ. Sci. Technol. 2018, 40, 4481-4487. [CrossRef]

16. Alam, Q.; Schollbach, K.; van Hoek, C.; van der Laan, S.; Wolf, T.; de Brouwers, H.J.H. In-depth mineralogical quantification of MSWI bottom ash phases and their association with potentially toxic elements. Waste Manag. 2019, 87, 1-12. [CrossRef]

17. Chimenos, J.M.; Segarra, M.; Fernández, M.A.; Espiell, F. Characterization of the bottom ash in municipal solid waste incinerator. J. Hazard. Mater. 1999, 64, 211-222. [CrossRef]

18. Alam, Q.; Lazaro, A.; Schollbach, K.; Brouwers, H.J.H. Chemical speciation, distribution and leaching behavior of chlorides from municipal solid waste incineration bottom ash. Chemosphere 2020, 241, 124985. [CrossRef]

19. Alam, Q.; Florea, M.V.A.; Schollbach, K.; Brouwers, H.J.H. A two-stage treatment for Municipal Solid Waste Incineration (MSWI) bottom ash to remove agglomerated fine particles and leachable contaminants. Waste Manag. 2017, 67, 181-192. [CrossRef]

20. Holm, O.; Simon, F.G. Innovative treatment trains of bottom ash (BA) from municipal solid waste incineration (MSWI) in Germany. Waste Manag. 2017, 59, 229-236. [CrossRef]

21. Steketee, J.J.; Duzijn, R.F.; Born, J.G.P. Quality Improvement of MSWI Bottom Ash by Enhanced Aging, Washing and Combination Processes. In Studies in Environmental Science: Waste Materials in Construction; Goumans, J.J.J.M., Senden, G.J., van der Sloot, H.A., Eds.; Elsevier: Amsterdam, The Netherlands, 1997; Volume 71, pp. 13-23. Available online: http://www.sciencedirect.com/ science/article/pii/S0166111697801847 (accessed on 10 April 2021).

22. Sun, X.; Yi, Y. Acid washing of incineration bottom ash of municipal solid waste: Effects of $\mathrm{pH}$ on removal and leaching of heavy metals. Waste Manag. 2021, 120, 183-192. [CrossRef]

23. Hu, Y.; Zhao, L.; Zhu, Y.; Zhang, B.; Hu, G.; Xu, B.; He, C.; Di Maio, F. The fate of heavy metals and salts during the wet treatment of municipal solid waste incineration bottom ash. Waste Manag. 2021, 121, 33-41. [CrossRef] 
24. Quek, A.; Xu, W.; Guo, L.; Wu, D. Heavy Metal Removal from Incineration Bottom Ash through Washing with Rainwater and Seawater. Int. J. Waste Resour. 2016, 6, 203. [CrossRef]

25. Alam, Q.; Schollbach, K.; Florea, M.V.A.; Brouwers, H.J.H. Investigating washing treatment to minimize leaching of chlorides and heavy metals from MSWI bottom ash. In Proceedings of the 4th International Conference on Sustainable Solid Waste Management, Limassol, Cyprus, 23 June 2016.

26. Swapan Kumar, H. (Ed.) Mineral Exploration. In Principles and Applications; Elsevier Science: San Diego, CA, USA, 2018.

27. Wills, B.A.; Finch, J.A. Chapter 7-Grinding Mills. In Wills' Mineral Processing Technology. An Introduction to the Practical Aspects of Ore Treatment and Mineral Recovery, 8th ed.; Wills, B.A., Finch, J., Eds.; Butterworth-Heinemann: Amsterdam, The Netherlands, 2015; pp. 147-179.

28. Ali, Y.; Garcia-Mendoza, C.D.; Gates, J.D. Effects of 'impact' and abrasive particle size on the performance of white cast irons relative to low-alloy steels in laboratory ball mills. Wear 2019, 426, 83-100. [CrossRef]

29. Barry, A.W. (Ed.) Wills' Mineral Processing Technology, 8th ed.; Butterworth-Heinemann: Boston, CA, USA, 2016.

30. Gupta, A.; Yan, D.S. Chapter 7-Tubular Ball Mills. In Mineral Processing Design and Operations, 7th ed.; Gupta, A., Yan, D.S., Eds.; Elsevier: Amsterdam, The Netherlands, 2016; pp. 189-240. [CrossRef]

31. Gupta, A.; Yan, D.S. Chapter 9-Autogenous and Semi-Autogenous Mills. In Mineral Processing Design and Operations, 6th ed.; Elsevier: Amsterdam, The Netherlands, 2016; pp. 234-254.

32. Deutsche Institut für Normung e.V. DIN 19528:2009-01, Elution von Feststoffen_- Perkolationsverfahren zur gemeinsamen Untersuchung des Elutionsverhaltens von anorganischen und organischen Stoffen. Available online: https://www.beuth.de/en/ standard/din-19528/104285985 (accessed on 25 May 2021).

33. Deutsche Institut für Normung e.V. Geotechnische Erkundung und Untersuchung_- Laborversuche an Bodenproben_- Teil_1: Bestimmung des Wassergehalts (ISO_17892-1:2014); Deutsche Fassung EN_ISO_17892-1:2014. Available online: https://www. beuth.de/en/standard/din-en-iso-17892-1/208096261 (accessed on 25 May 2021).

34. Deutsche Institut für Normung e.V. DIN EN 933-1:2012-03, Prüfverfahren für geometrische Eigenschaften von Gesteinskörnungen_Teil_1: Bestimmung der Korngrößenverteilung_- Siebverfahren; Deutsche Fassung EN_933-1:2012. Available online: https: / / www.beuth.de/en/standard/din-en-933-1/148605855 (accessed on 25 May 2021).

35. Deutsche Institut für Normung e.V. DIN 38405-1:1985-12, Deutsche Einheitsverfahren zur Wasser-, Abwasser- und Schlammuntersuchung; Anionen (Gruppe_D); Bestimmung der Chlorid-Ionen_(D_1). Available online: https://www.beuth.de/en/standard/ din-38405-1/1263215 (accessed on 25 May 2021).

36. Arickx, S.; de Borger, V.; van Gerven, T.; Vandecasteele, C. Effect of carbonation on the leaching of organic carbon and of copper from MSWI bottom ash. Waste Manag. 2010, 30, 1296-1302. [CrossRef]

37. Hyks, J.; Astrup, T.; Christensen, T.H. Leaching from MSWI bottom ash: Evaluation of non-equilibrium in column percolation experiments. Waste Manag. 2009, 29, 522-529. [CrossRef]

38. Nilsson, M.; Andreas, L.; Lagerkvist, A. Effect of accelerated carbonation and zero valent iron on metal leaching from bottom ash. Waste Manag. 2016, 51, 97-104. [CrossRef] 